University of Nebraska - Lincoln

DigitalCommons@University of Nebraska - Lincoln

\title{
Effect of Oxygen Management on Culture Performance of Channel Catfish in Earthen Ponds
}

\author{
Eugene L. Torrans \\ United States Department of Agriculture, Itorrans@ars.usda.gov
}

Follow this and additional works at: https://digitalcommons.unl.edu/usdaarsfacpub

Part of the Agricultural Science Commons

Torrans, Eugene L., "Effect of Oxygen Management on Culture Performance of Channel Catfish in Earthen Ponds" (2005). Publications from USDA-ARS / UNL Faculty. 601.

https://digitalcommons.unl.edu/usdaarsfacpub/601

This Article is brought to you for free and open access by the U.S. Department of Agriculture: Agricultural Research Service, Lincoln, Nebraska at DigitalCommons@University of Nebraska - Lincoln. It has been accepted for inclusion in Publications from USDA-ARS / UNL Faculty by an authorized administrator of DigitalCommons@University of Nebraska - Lincoln. 


\title{
Effect of Oxygen Management on Culture Performance of Channel Catfish in Earthen Ponds
}

\author{
Eugene L. TORRANS* \\ U.S. Department of Agriculture, Agricultural Research Service, \\ Thad Cochran National Warmwater Aquaculture Center, Catfish Genetics Research Unit, \\ Post Office Box 38, Stoneville, Mississippi 38776, USA
}

\begin{abstract}
Aeration allows for higher feeding rates and increased production of channel catfish Ictalurus punctatus in intensive and semi-intensive aquaculture systems. However, the effect of specific dissolved oxygen (DO) concentrations on various production parameters remains unknown. The purpose of this 2-year study was to determine the effect of daily minimum DO concentration on channel catfish production. Six 0.1 -ha ponds were each equipped with three $0.37-\mathrm{kW}(0.5-\mathrm{hp})$ aerators and one $0.37-\mathrm{kW}$ circulator. Dissolved oxygen concentrations were monitored and recorded with a commercial oxygen monitor that also controlled aeration. During both years, aeration in the high-oxygen treatment was initiated when the DO concentration dropped below $5.0 \mathrm{mg} / \mathrm{L}$ (mean, 64\% saturation from May to September); aeration in the low-oxygen treatment was initiated when the DO concentration dropped below $2.5 \mathrm{mg} / \mathrm{L}$ (32\% saturation; 2001) or $1.5 \mathrm{mg} / \mathrm{L}$ (19\% saturation; 2002). The minimum DO concentrations resulting from this aeration protocol differed somewhat from aerator set points. In the low-oxygen treatment, delaying aeration until the DO concentration dropped below $2.5 \mathrm{mg} / \mathrm{L}$ reduced feed consumption by $6 \%$ relative to the highoxygen treatment. Other production parameters were not significantly different. In 2002, when aeration was delayed until the DO concentration dropped below $1.5 \mathrm{mg} / \mathrm{L}$, the low-oxygen treatment group exhibited reductions in food consumption ( $45 \%$ less than consumption by the high-oxygen treatment), average fish weight (31\% less), and net production ( $54 \%$ less). Even at the high feeding rates of 2002 (maximum of $680 \mathrm{~kg} \cdot \mathrm{ha}^{-1} \cdot \mathrm{d}^{-1} ; 44,066 \mathrm{~kg} / \mathrm{ha}$ total in one pond), other water quality variables were acceptable. Net production in the high-oxygen treatment in 2002 averaged 23,547 $\mathrm{kg} / \mathrm{ha}$, a potential record for channel catfish in earthen ponds. Neither the feed conversion ratio nor survival was significantly different between treatments in either year. While these results cannot be directly extrapolated to large commercial ponds, it appears that increased aeration may increase production well above current commercial levels.
\end{abstract}

During the past 30 years, average production rates of channel catfish Ictalurus punctatus in commercial ponds have increased from $1,130 \mathrm{~kg} / \mathrm{ha}$ $(1,000 \mathrm{lb} / \mathrm{acre})$ to $3,400-6,800 \mathrm{~kg} / \mathrm{ha}(3,000-6,000$ $\mathrm{lb} / \mathrm{acre})$. Some individual farmers are producing as much as $13,608 \mathrm{~kg} / \mathrm{ha}(12,000 \mathrm{lb} / \mathrm{acre})$ on a wholefarm basis (George Smelley, Harvest Select Catfish, personal communication). This increase in production is due largely to the higher stocking and feeding rates made possible by increased aeration.

Swingle (1959) recommended a maximum safe feeding rate of $34 \mathrm{~kg} \cdot \mathrm{ha}^{-1} \cdot \mathrm{d}^{-1}$ in unaerated ponds. At this feeding rate, dissolved oxygen (DO) provided by wind action and photosynthesis of the algal bloom is normally sufficient to meet the oxygen demands of the fish, the bloom, and the sediment, and emergency mechanical aeration is rare-

\footnotetext{
* Corresponding author: 1torrans@ars.usda.gov
}

Received November 9, 2004; accepted March 30, 2005 Published online August 1, 2005 ly needed to keep the fish alive through the night (Tucker et al. 1979). Tucker and Boyd (1978) suggested that 2,500-3,000 kg/ha of channel catfish may be produced annually in unaerated ponds without serious risk of oxygen depletion.

As farmers increased fish stocking and feeding rates in an effort to grow more fish, problems with low DO concentrations increased in frequency and severity and emergency aeration was required more frequently (Tucker et al. 1979; Boyd et al. 1980). When most ponds on a farm required emergency aeration on a nightly basis (in the late 1970s and early 1980s), farmers permanently installed more-efficient electric aerators in each pond (Busch et al. 1984). These aerators are normally activated at night or in response to periodic DO measurements and are turned off in the morning when the DO concentrations begin to increase from photosynthesis.

Channel catfish feeding and production rates have increased approximately in proportion to aeration rate. Increased aeration reduces the frequency and magnitude of oxygen depletion events, al- 
lowing higher feeding rates (Hollerman and Boyd 1980). Most commercial channel catfish ponds have $3.5-4.7 \mathrm{~kW} / \mathrm{ha}(1-2 \mathrm{hp} / \mathrm{acre})$ of permanently installed electric paddlewheel aerators for routine aeration (USDA 1997), and additional portable tractor-powered units are kept for emergency use.

While laboratory research indicates that channel catfish respiration, food consumption, growth, and feed conversion ratio (FCR) are reduced at constant below-saturation DO concentrations (Andrews et al. 1973; Andrews and Matsuda 1975; Raible 1975; Buentello et al. 2000), the effects of fluctuating DO concentrations, which are typical in eutrophic channel catfish ponds in the summer, are not well known. Carlson et al. (1980) demonstrated that channel catfish consume less food and exhibit reduced growth when held at mean constant DO concentrations than when held at diurnally fluctuating DO concentrations. However, the range of DO concentrations used in that study was much narrower $(2.0-4.9 \mathrm{mg} / \mathrm{L})$ than the ranges normally encountered in intensively managed warmwater channel catfish ponds (Hargreaves and Steeby 2000).

In lieu of better data on the response of channel catfish to highly variable DO concentrations, most management strategies used since the early days of channel catfish farming (e.g., periodic DO measurements, aeration, water exchange, reduction in feeding rates, and use of algicides) have been aimed at preventing catastrophic oxygen-related fish kills and minimizing visible fish stress. Channel catfish mortality may normally be expected in ponds when the DO concentration falls below 1 mg/L (Moss and Scott 1961; Chowdhury 1971; Durborow et al. 1985). Channel catfish raised in ponds exhibit reduced feed intake on afternoons after episodes of acute (visible) oxygen stress (Tucker et al. 1979). Pond studies have indicated reduced feed consumption (Hargreaves and Steeby 2000) or feed conversion (Lai-fa and Boyd 1988) when DO concentration falls to $2.0 \mathrm{mg} / \mathrm{L}$ or less. However, pond studies in which specific minimum DO concentrations are maintained have not been conducted.

Given the dynamic pond environment and the lack of applied data upon which to base aeration decisions, it is no surprise that oxygen management plans vary widely among channel catfish farms. Some farmers routinely begin aeration before the DO concentration falls to $4 \mathrm{mg} / \mathrm{L}$. Other farmers set a DO concentration of $2 \mathrm{mg} / \mathrm{L}$ as the threshold to begin aeration. Most farmers begin aeration at some point between those two extremes
(Tucker and Robinson 1990) and turn on additional electric aerators and eventually tractor-powered aerators if the DO concentration continues to fall.

The purpose of this 2-year study was to determine the effect of daily minimum DO concentration on feed consumption, feed conversion, growth, and production of channel catfish grown in earthen ponds. Additionally, the impacts of minimum DO concentration on other water quality variables were examined.

\section{Methods}

Production studies were conducted in 2001 and 2002 at the U.S. Department of Agriculture (USDA), Agricultural Research Service (ARS), Catfish Genetics Research Unit at Stoneville, Mississippi. Six 0.1 -ha ponds with a $1.2-\mathrm{m}$ average depth were used in the study. During both years, ponds were stocked before fish began to actively feed in the spring and were completely harvested in the fall after feeding had ceased.

Each pond was treated with $1.9 \mathrm{~L}$ of Aquashade (Applied Biochemists, Alpharetta, Georgia) and $0.95 \mathrm{~L}$ of 11-37-0 liquid fertilizer during filling. Water levels were maintained throughout the study by a $6 / 3$ water management system to minimize water exchange (Cathcart et al. 1999). Both alkalinity and hardness exceeded $200 \mathrm{mg} / \mathrm{L}$ and did not differ significantly between treatments during either year.

Each pond was equipped with a Royce Model 9300 oxygen analyzer connected to a Model 95 oxygen sensor (Royce Instrument Corp., New Orleans, Louisiana). The oxygen sensors were aircalibrated once daily. The sensors and analyzers were used for data collection via radio link to a desktop computer and were used to control three 0.37-kW (0.5-hp) paddlewheel aerators (Southern Machine Welding, Inc., Quinton, Alabama) in each pond. Aerators were activated individually as stipulated by the experimental design. Dissolved oxygen concentration, water temperature, and aerator status were continuously monitored and recorded every 20 min throughout the study. Additionally, one $0.37-\mathrm{kW}$ vertical pump aerator (Kasco Marine, Inc., Prescott, Wisconsin), which was mounted horizontally under a float, was run continuously as a circulator in each pond to minimize temperature and oxygen stratification (Busch and Goodman 1981; Tucker and Steeby 1995). The circulator and aerators were positioned to create counterclockwise circulation in the pond when operating.

Rock salt (Cargill, Inc., Minneapolis, Minne- 
TABLE 1.-Mean weights and numbers ( \pm SEs) of channel catfish stocked in earthen ponds on March 12 (2-year-old "large fish") and March 13, 2001 (1-year-old "small fish"). None of the variables differed significantly between treatments (ANOVA).

\begin{tabular}{lcc}
\hline \multirow{2}{*}{\multicolumn{1}{c}{ Variable }} & \multicolumn{2}{c}{ Treatment } \\
\cline { 2 - 3 } \multicolumn{1}{c}{ Low oxygen } & High oxygen \\
\hline Large fish stocked $(\mathrm{kg} / \mathrm{ha})$ & $5,652 \pm 56$ & $5,818 \pm 61$ \\
Large fish stocked (number/ha) & $15,072 \pm 104$ & $14,973 \pm 10$ \\
Small fish stocked (kg/ha) & $708 \pm 0$ & $708 \pm 0$ \\
Small fish stocked (number/ha) & $40,000 \pm 0$ & $40,000 \pm 0$ \\
Total weight of fish stocked (kg/ha) & $6,359 \pm 56$ & $6,526 \pm 61$ \\
Total fish stocked (number/ha) & $55,072 \pm 104$ & $54,973 \pm 10$ \\
\hline
\end{tabular}

sota) was added to raise chloride concentrations to $100 \mathrm{mg} / \mathrm{L}$ as a prophylaxis against nitriteinduced methemoglobinemia (Tomasso et al. 1980). Based on weekly chloride measurement, additional salt was added to individual ponds to maintain a minimum chloride concentration of 100 mg/L (Brunson 1997).

Once daily, fish were fed all they would consume in $10 \mathrm{~min}$. Feeding frequency was increased from once per week to twice per week, then every other day, and then daily as water temperature and feeding response increased through the spring. Feeding frequency decreased similarly in the fall as water temperatures decreased. Fish were fed a $28 \%$-protein floating feed in 2001; a 32\%-protein feed was used in 2002 (Delta Western Catfish Feed, Indianola, Mississippi).

Dead fish were collected daily. Fish diagnosed with Edwardsiella ictaluri (the causative agent of enteric septicemia of catfish [ESC]) were fed a $32 \%$-protein commercial feed containing Romet$30(0.28 \mathrm{~g}$ of sulfadimethoxine $/ \mathrm{kg}$ of feed and 0.06 $\mathrm{g}$ of ormetroprim $/ \mathrm{kg}$ of feed) for $5 \mathrm{~d}$; fish diagnosed with Flavobacterium columnare were fed a $32 \%$-protein commercial feed containing oxytetracycline $(1.13 \mathrm{~g} / \mathrm{kg})$ for $10 \mathrm{~d}$ (Delta Western Catfish Feed).

Water quality data were analyzed with the repeated-measures analysis of variance (ANOVA) procedure in SAS/STAT Analyst Application (SAS Institute 1999a, 1999b); repeated measures were taken on replicate ponds at approximately weekly intervals. The covariance structure, autoregressive of order 1, was used in the repeated-measures model. Mean comparisons were made with a leastsignificant-difference test. Production data were analyzed by use of ANOVA with a significance level of 0.05 unless otherwise stated.

2001 study._Ponds were filled with well water during the week of March 5-9 and were stocked on March 12 (Table 1) with 2-year-old USDA103 channel catfish (15,000 fish/ha) and again on March 13, 2001, with 1-year-old USDA103 fingerlings (40,000 fish/ha). These fish came from an experimental line currently maintained at the USDA-ARS Catfish Genetics Research Unit; this line was recently released to the industry by Mississippi State University under the name NWAC103 (New catfish broodstock moved to growers 2001). Two size-groups were used to simulate the mixed-size culture system currently used by most commercial farmers. To control aquatic macrophytes, each pond was also stocked on April 17 with 10 grass carp Ctenopharyngodon idella averaging $0.8 \mathrm{~kg}$.

A high-oxygen treatment was randomly assigned to three ponds; three paddlewheel aerators in each pond operated sequentially when the DO concentration dropped below 5.0, 4.5, and $4.0 \mathrm{mg} /$ $\mathrm{L}$, respectively. A low-oxygen treatment was assigned to three ponds, and the three aerators in each pond operated sequentially as DO concentration dropped below $2.5,2.3$, and $2.0 \mathrm{mg} / \mathrm{L}$. Individual aerators were turned off automatically when the DO concentration increased above the actuation set points.

Ponds were sampled weekly for chloride, $\mathrm{pH}$, ammonia, and nitrite. Chloride was determined by means of the silver nitrate method (Hach Co., Loveland, Colorado). Total ammonia nitrogen (TAN) was determined with the phenate method, and nitrite-nitrogen $\left(\mathrm{NO}_{2}-\mathrm{N}\right)$ was determined by use of diazotization (Boyd and Tucker 1992). Unionized ammonia nitrogen $\left(\mathrm{NH}_{3}-\mathrm{N}\right)$ was calculated as a function of TAN, temperature, and $\mathrm{pH}$ (Emerson et al. 1975).

Market-size fish (larger specimens of the 2-yearold age-class) were selectively harvested on $\mathrm{Au}$ gust 29 and again on October 25 with a $4.8-\mathrm{cm}$ (1.875-in) stretch-mesh net that retained fish larger than approximately $0.6 \mathrm{~kg}(1.3 \mathrm{lb})$. Ponds were completely harvested on November 6-8. 


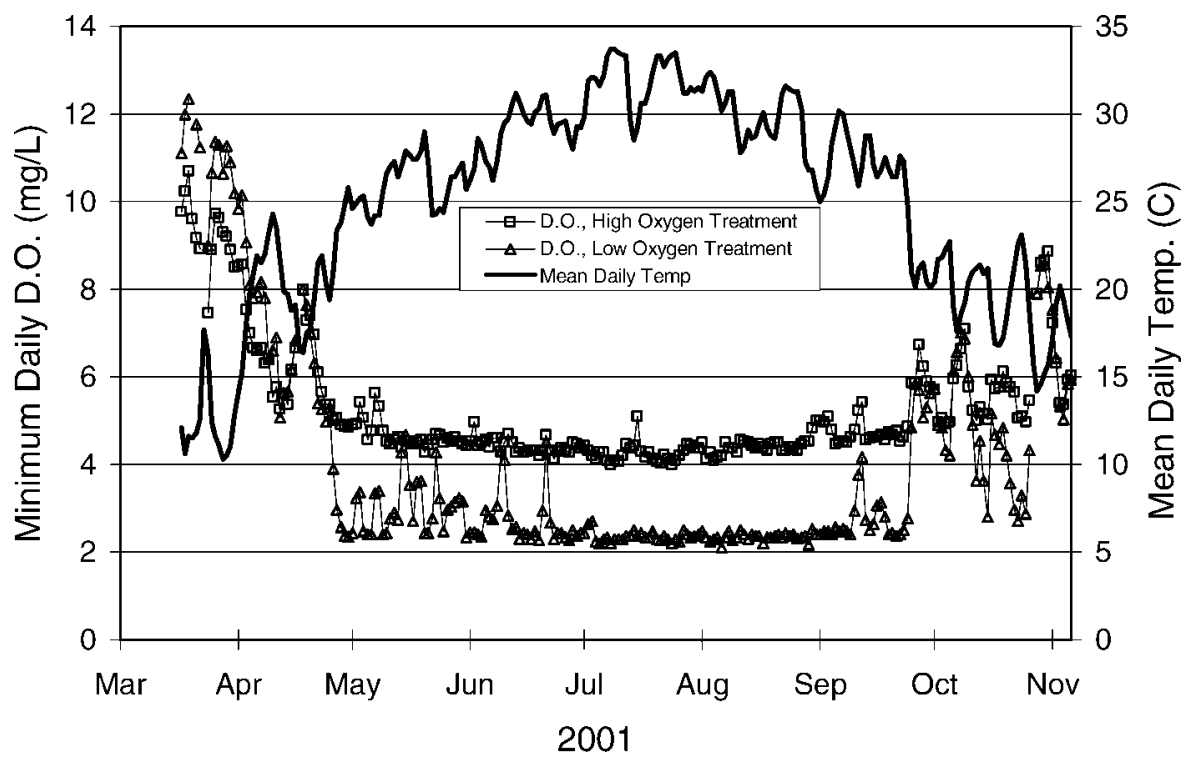

FIGURE 1.-Minimum daily dissolved oxygen (DO) concentrations and mean daily temperature in experimental channel catfish ponds in 2001. Values for DO are daily means of the lowest daily DO concentration in three 0.1 ha ponds per treatment; temperature is the mean of 72 daily measurements recorded from one representative pond.

2002 study.-Ponds were filled with well water during the week of February 11-15 and were stocked on February 25-26 with 1,485 kg/ha of 1year-old USDA103 channel catfish. These 12-20$\mathrm{cm}$ (total length [TL]) graded fingerlings had an average weight of $37 \mathrm{~g}$ (82 lb/1,000 fish), resulting in a stocking rate of 40,000 fish/ha. The channel catfish had been vaccinated as fry during the pre-

TABLE 2.-Monthly mean ( $\pm \mathrm{SE})$ water temperature, minimum dissolved oxygen (DO) concentration, and percent oxygen saturation in experimental channel catfish ponds (three replicates/treatment) in 2001. Measurements were taken on pond water returning to the aerators, prior to aeration. Mean percent oxygen saturation (in parentheses) is based on the mean temperature, which was measured in one representative pond. Within a row, oxygen values followed by different letters are significantly different (ANOVA; $P \leq 0.05$ ).

\begin{tabular}{lccc}
\hline & & \multicolumn{2}{c}{ DO $(\mathrm{mg} / \mathrm{L})(\%$ saturation $)$} \\
\cline { 3 - 4 } Month & $\begin{array}{c}\text { Temperature } \\
\left({ }^{\circ} \mathrm{C}\right)\end{array}$ & $\begin{array}{c}\text { Low-oxygen } \\
\text { treatment }\end{array}$ & $\begin{array}{c}\text { High-oxygen } \\
\text { treatment }\end{array}$ \\
\hline Mar & $12.3 \pm 0.5$ & $11.1 \pm 2.2(104)$ & $9.3 \pm 0.1(87)$ \\
Apr & $20.4 \pm 0.5$ & $6.3 \pm 0.8(70)$ & $6.3 \pm 0.2(70)$ \\
May & $26.0 \pm 0.3$ & $3.0 \pm 0.1(37) \mathrm{y}$ & $4.7 \pm 0.0(58) \mathrm{z}$ \\
Jun & $29.1 \pm 0.3$ & $2.6 \pm 0.1(34) \mathrm{y}$ & $4.4 \pm 0.0(57) \mathrm{z}$ \\
Jul & $32.0 \pm 0.3$ & $2.4 \pm 0.0(33) \mathrm{y}$ & $4.3 \pm 0.1(59) \mathrm{z}$ \\
Aug & $29.8 \pm 0.3$ & $2.3 \pm 0.0(30) \mathrm{y}$ & $4.4 \pm 0.1(58) \mathrm{z}$ \\
Sep & $26.0 \pm 0.6$ & $3.2 \pm 0.2(40) \mathrm{y}$ & $5.0 \pm 0.1(62) \mathrm{z}$ \\
Oct & $19.3 \pm 0.5$ & $5.1 \pm 0.4(55)$ & $5.9 \pm 0.2(64)$ \\
Nov & $18.6 \pm 0.5$ & $6.0 \pm 0.1(64)$ & $6.0 \pm 0.1(64)$ \\
\hline
\end{tabular}

vious year with AQUAVAC-ESC (Intervet, Inc., Millsboro, Delaware).

The three aerators in each high-oxygen treatment pond were actuated sequentially as the DO concentration dropped below 5.0, 4.9, and $4.8 \mathrm{mg} /$ L. The three aerators in each low-oxygen treatment pond were actuated when the DO concentration dropped below $1.5,1.4$, and $1.3 \mathrm{mg} / \mathrm{L}$.

Chloride, $\mathrm{pH}$, ammonia, nitrite, chlorophyll $a$ (a measure of phytoplankton biomass; Lloyd and Tucker 1988), nitrate (Boyd and Tucker 1992), suspended solids (fixed, volatile, and total), Secchi disk visibility, alkalinity, and hardness (American Public Health Association et al. 1998) were determined weekly.

Harvest began on November 4 (252 d after stocking) and was completed in $3 \mathrm{~d}$.

\section{Results}

\section{Study}

Oxygen.-The intended treatment (different minimum DO concentrations) was effectively applied to the ponds (Figure 1). From May to September, monthly mean water temperature averaged higher than $25^{\circ} \mathrm{C}$ and the minimum DO concentration in the high-oxygen treatment was significantly higher than that of the low-oxygen treatment (Table 2). Mean monthly minimum DO concentration ranged from 4.3 to $5.0 \mathrm{mg} / \mathrm{L}$ in the high- 


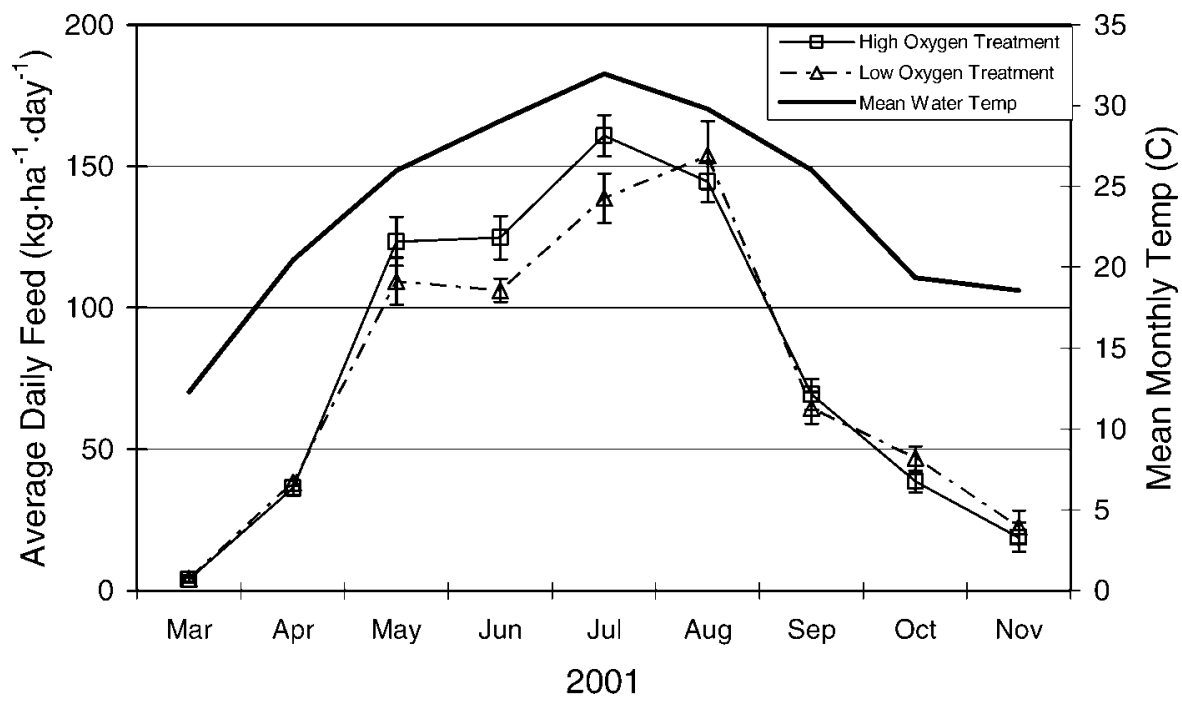

FIGURE 2.- Average $( \pm$ SE) daily feed administered to experimental channel catfish ponds in 2001. Feed values are monthly means of three replicate ponds per treatment; temperature is the mean value for one representative pond.

oxygen treatment versus $2.3-3.2 \mathrm{mg} / \mathrm{L}$ in the low-oxygen treatment (59\% versus $35 \%$ saturation), a mean difference of $1.9 \mathrm{mg} / \mathrm{L}$, during those months. There were no significant differences between treatments in March, April, October, and November, months in which water temperature averaged less than $21^{\circ} \mathrm{C}$. Due to the low water temperatures, only $12.3 \%$ of the season's feed was given in those 4 months (Figure 2).

Feed.-Feed consumption in both treatments ranged from less than $23 \mathrm{~kg} \cdot \mathrm{ha}^{-1} \cdot \mathrm{d}^{-1}$ in March and November to over $138 \mathrm{~kg} \cdot \mathrm{ha}^{-1} \cdot \mathrm{d}^{-1}$ in July and August (Figure 2). The highest monthly feeding rate $\left(161 \mathrm{~kg} \cdot \mathrm{ha}^{-1} \cdot \mathrm{d}^{-1}\right)$ was observed in the high-oxygen treatment in July, the month with the highest mean water temperature.

While the minimum daily DO concentration averaged $1.9 \mathrm{mg} / \mathrm{L}$ lower in the low-oxygen treatment than in the high oxygen treatment from May to September (from Table 2), there were no significant differences in feed consumption during any individual month (Figure 2). However, fish in the low-oxygen treatment consumed significantly less feed overall (6.3\%; Table 3) than fish in the high-oxygen treatment $(20,139$ versus $21,501 \mathrm{~kg} /$ ha; $P$ 0.05).

Production.-There were no significant differences in net production, survival, or FCR between treatments (Table 3). Survival did not differ significantly between treatments but was negatively correlated with average weight (Figure $3 ; r^{2}=$
$-0.89, P \leq 0.005)$. Thus, the slightly larger average fish weight in the high-oxygen treatment ponds may be due at least in part to the slightly lower survival in that treatment.

Most observed mortality was due to ESC; $69.9 \%$ (data not shown) of observed mortality occurred during June, when water temperatures were in the optimum range for this disease. Many fish of the larger size-class died during this period. These fish had been harvested during the previous fall after feeding had ceased, were stored in a pond over winter, and were restocked in the study ponds before feeding began in the spring of 2001. They were in visibly poor condition when stocked in the spring of 2001. The loss of these large fish accounts for a large part of the poor FCR.

Aeration hours.-Maintaining higher oxygen levels required significantly more aeration. The high-oxygen treatment used significantly more aeration every month from April to October and $160 \%$ more overall than did the low-oxygen treatment (Table 4). To put this in perspective, the 2,735-kilowatt-hours $(\mathrm{kW}-\mathrm{h}) /$ ha aeration in the high-oxygen treatment during August, the month of peak aeration treatment, would require each of the three $0.37-\mathrm{kW}$ paddlewheel aerators present in each 0.1-ha pond to run for an average of $7.9 \mathrm{~h} /$ d. By contrast, the three aerators in each lowoxygen treatment pond would each need to run an average of $3.3 \mathrm{~h} / \mathrm{d}$ during the same month.

The high-oxygen treatment used an average of 
TABLE 3.-Average $( \pm \mathrm{SE})$ weight, gross production, net production, survival, and feed conversion ratio of channel catfish in 0.1-ha earthen ponds (three ponds/treatment) in 2001. Within a row, values followed by different letters are significantly different (ANOVA; $P \leq 0.05$ ).

\begin{tabular}{lcc}
\hline \multicolumn{1}{c}{ Variable } & Low-oxygen treatment & High-oxygen treatment \\
\hline Partial harvest (kg/ha) & $7,740 \pm 474$ & $8,060 \pm 389$ \\
Partial harvest average weight $(\mathrm{kg})$ & $0.82 \pm 0.02 \mathrm{y}$ & $0.90 \pm 0.01 \mathrm{z}$ \\
Final harvest $(\mathrm{kg} / \mathrm{ha})$ & $5,643 \pm 173$ & $5,333 \pm 247$ \\
Final harvest average weight $(\mathrm{kg})$ & $0.21 \pm 0.01 \mathrm{y}$ & $0.23 \pm 0.0 \mathrm{z}$ \\
Gross production (kg/ha) & $13,383 \pm 305$ & $13,393 \pm 304$ \\
Gross production average weight $(\mathrm{kg})$ & $0.37 \pm 0.02$ & $0.41 \pm 0.01$ \\
Net production (kg/ha) & $7,023 \pm 249$ & $6,868 \pm 243$ \\
Survival (\%) & $66.3 \pm 2.1$ & $59.2 \pm 2.3$ \\
Feed administered (kg/ha) & $20,139 \pm 87 \mathrm{y}$ & $21,501 \pm 273 \mathrm{z}$ \\
Feed conversion ratio & $2.87 \pm 0.11$ & $3.13 \pm 0.09$ \\
\hline
\end{tabular}

$8,041 \mathrm{~kW}-\mathrm{h} / \mathrm{ha}$ of aeration during the year, in contrast to $3,096 \mathrm{~kW}-\mathrm{h} / \mathrm{ha}$ for the low-oxygen ponds. At a cost of $\$ 0.11$ per kilowatt-hour, this would add $\$ 0.12$ versus $\$ 0.05$ per kilogram to the cost of fish in the high- and low-oxygen treatments, respectively. On a commercial farm, these extra hours of operation would add additional maintenance and capital equipment costs as well.

Water quality.-Most water quality variables followed the same general seasonal trend as water temperature and feed consumption, but there was great variation on any sample date. Total ammonia nitrogen, un-ionized ammonia nitrogen, and nitrate-nitrogen $\left(\mathrm{NO}_{3}-\mathrm{N}\right)$ did not differ significantly between the high- and low-oxygen treatments (Table 5). Un-ionized ammonia was generally less than $0.05 \mathrm{mg} / \mathrm{L}$; the highest concentration determined for any single sample during the year was $0.14 \mathrm{mg} / \mathrm{L}$ on August 10. This was well below the concentration shown to have an effect on channel catfish food consumption or growth (Hargreaves and Kucuk 2001).

While not biologically significant, nitritenitrogen was significantly higher in the highoxygen treatment than in the low-oxygen treatment (Table 5). Nitrification is an aerobic process (Bru-

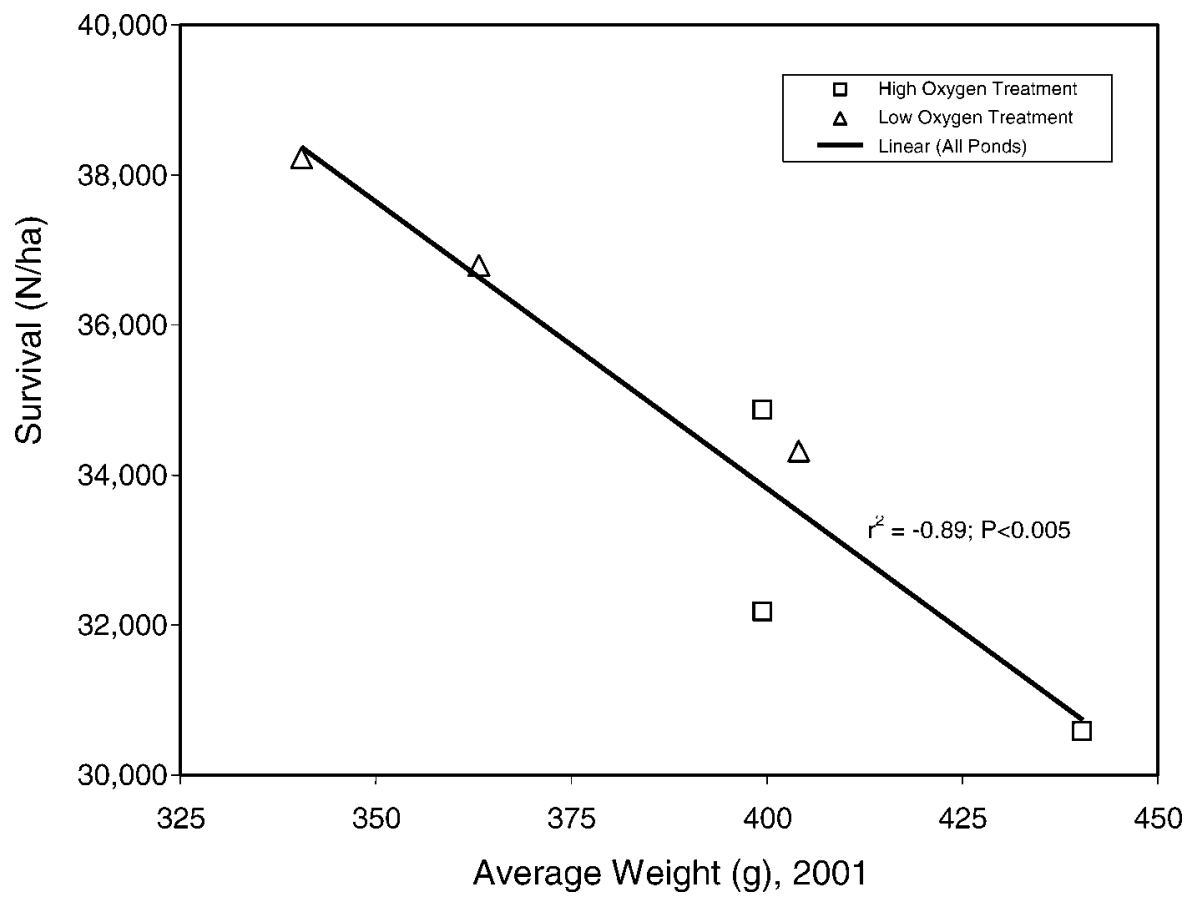

FIGURE 3.- Actual survival (number of fish recovered) versus average weight of channel catfish harvested from experimental ponds in 2001 . 
TABLE 4.-Aeration levels (kilowatt-hours [kW-h]/ha; mean $\pm \mathrm{SE}$ ) in experimental channel catfish ponds (three ponds/treatment) in 2001. Temperature is the mean monthly temperature $\left({ }^{\circ} \mathrm{C}\right)$ measured in one representative pond. Within a row, values followed by different letters are significantly different (ANOVA; $P \leq 0.05$ ).

\begin{tabular}{lccc}
\hline & \multicolumn{2}{c}{ Aeration } & \\
\cline { 2 - 3 } Month & $\begin{array}{c}\text { Low-oxygen } \\
\text { treatment }\end{array}$ & $\begin{array}{c}\text { High-oxygen } \\
\text { treatment }\end{array}$ & Temperature \\
\hline Mar & $0 \pm 0$ & $0 \pm 0$ & 12.3 \\
Apr & $39 \pm 16 \mathrm{y}$ & $120 \pm 6 \mathrm{z}$ & 20.4 \\
May & $274 \pm 45 \mathrm{y}$ & $755 \pm 152 \mathrm{z}$ & 26.0 \\
Jun & $439 \pm 103 \mathrm{y}$ & $1,000 \pm 106 \mathrm{z}$ & 29.1 \\
Jul & $875 \pm 87 \mathrm{y}$ & $1,963 \pm 217 \mathrm{z}$ & 32.0 \\
Aug & $1,160 \pm 48 \mathrm{y}$ & $2,735 \pm 55 \mathrm{z}$ & 29.8 \\
Sep & $317 \pm 48 \mathrm{y}$ & $1,284 \pm 190 \mathrm{z}$ & 26.0 \\
Oct & $1 \pm 1 \mathrm{y}$ & $182 \pm 68 \mathrm{z}$ & 19.3 \\
Nov & $0 \pm 0$ & $2 \pm 2$ & 18.6 \\
Total & $3,096 \pm 245 \mathrm{y}$ & $8,041 \pm 390 \mathrm{z}$ & \\
\hline
\end{tabular}

ne et al. 2003), and the increased aeration in the high-oxygen treatment ponds probably facilitated the transformation of ammonia (which was slightly but not significantly decreased in the high-oxygen treatment) to nitrite. Nitrite-nitrogen peaked in August and September but never exceeded 0.94 $\mathrm{mg} / \mathrm{L}$ (measured on August 30). This is less than $10 \%$ of the allowable concentration based on the chloride concentrations that were maintained (Tomasso et al. 1980; Brunson 1997; Durborow et al. 1997).

The $\mathrm{pH}$ differed significantly between treatments, averaging 8.01 in the high-oxygen treatment versus 7.96 in the low-oxygen treatment. The slightly higher $\mathrm{pH}$ values in the high-oxygen treatment may be due to a greater loss of $\mathrm{CO}_{2}$ to the atmosphere in ponds that received more aeration (Hargreaves and Brunson 1996).

\section{Study}

Fish in two ponds experienced high mortality in June. One pond in the low-oxygen treatment had an equipment failure that resulted in an oxygen depletion event; one pond in the high-oxygen treat-
TABLE 6.- Monthly mean ( \pm SE) water temperature, minimum dissolved oxygen (DO) concentration, and percent oxygen saturation in experimental channel catfish ponds (two replicates/treatment) in 2002. Measurements were taken on pond water returning to the aerators, prior to aeration. Mean percent oxygen saturation (in parentheses) is based on the mean temperature, which was measured in one representative pond. Within a row, oxygen values followed by different letters are significantly different (ANOVA; $P \leq 0.05$ ).

\begin{tabular}{lccc}
\hline & & \multicolumn{2}{c}{ DO $(\mathrm{mg} / \mathrm{L})(\%$ saturation $)$} \\
\cline { 3 - 4 } Month & $\begin{array}{c}\text { Mean tempera- } \\
\text { ture }\left({ }^{\circ} \mathrm{C}\right)\end{array}$ & $\begin{array}{c}\text { Low-oxygen } \\
\text { treatment }\end{array}$ & $\begin{array}{c}\text { High-oxygen } \\
\text { treatment }\end{array}$ \\
\hline Mar & $13.3 \pm 0.7$ & $9.8 \pm 0.1(93)$ & $9.8 \pm 0.0(93)$ \\
Apr & $21.7 \pm 0.8$ & $6.4 \pm 0.1(73)$ & $6.5 \pm 0.1(74)$ \\
May & $24.4 \pm 0.4$ & $4.2 \pm 0.1(51) \mathrm{y}$ & $5.4 \pm 0.1(65) \mathrm{z}$ \\
Jun & $28.9 \pm 0.2$ & $1.6 \pm 0.1(21) \mathrm{y}$ & $4.7 \pm 0.0(61) \mathrm{z}$ \\
Jul & $31.5 \pm 0.1$ & $2.0 \pm 0.1(27) \mathrm{y}$ & $4.1 \pm 0.3(55) \mathrm{z}$ \\
Aug & $30.0 \pm 0.3$ & $1.3 \pm 0.1(17) \mathrm{y}$ & $4.0 \pm 0.1(53) \mathrm{z}$ \\
Sep & $26.7 \pm 0.5$ & $1.8 \pm 0.0(20) \mathrm{y}$ & $4.6 \pm 0.1(58) \mathrm{z}$ \\
Oct & $20.9 \pm 0.6$ & $2.8 \pm 0.5(31)$ & $4.7 \pm 0.0(53)$ \\
Nov & $13.0 \pm 0.7$ & $6.1 \pm 0.1(58)$ & $5.5 \pm 0.3(52)$ \\
\hline
\end{tabular}

ment had a serious outbreak of ESC. Since the known fish loss in both ponds exceeded $75 \%$ of initial stocking, it was decided at that time to drop them from the production study. While the surviving fish in both ponds were fed for the rest of the study, data from those two ponds were included only in the correlation analysis of survival versus average weight.

Oxygen.-Monthly mean minimum DO concentrations in the low-oxygen treatment ranged from 1.3 to $2.0 \mathrm{mg} / \mathrm{L}(17-27 \%$ saturation) from June to September, months in which the mean water temperature averaged $25^{\circ} \mathrm{C}$ or higher (Table 6). These values were somewhat higher (except for August) than the aeration set point, because there were a number of days in which the DO concentration never dropped low enough for aeration to commence (Figure 4). With the exception of 1 week in early July, when aerator set points were raised to high-oxygen treatment set points in response to initial symptoms of proliferative gill disease, days

TABLE 5.-Water quality variables (mean $\pm \mathrm{SE} ; N$ and maximum value in parentheses) for experimental channel catfish ponds (three ponds/treatment) in 2001. Measurements were taken at approximately weekly intervals throughout the study. The last column indicates the results of a repeated-measures ANOVA testing for significant differences between treatments (NS = not significant).

\begin{tabular}{lccc}
\hline \multicolumn{1}{c}{ Variable } & Low-oxygen treatment & High-oxygen treatment & $P$ \\
\hline Total ammonia nitrogen $(\mathrm{mg} / \mathrm{L})$ & $0.38 \pm 0.04(78,2.31)$ & $0.37 \pm 0.05(78,1.65)$ & NS \\
Un-ionized ammonia nitrogen $(\mathrm{mg} / \mathrm{L})$ & $0.017 \pm 0.003(50,0.141)$ & $0.022 \pm 0.004(51,0.144)$ & NS \\
pH & $7.96 \pm 0.04(50,8.61)$ & $8.01 \pm 0.03(51,8.50)$ & $\leq 0.01$ \\
Nitrite-nitrogen $(\mathrm{mg} / \mathrm{L})$ & $0.19 \pm 0.02(84,0.94)$ & $0.24 \pm 0.03(84,0.90)$ & $\leq 0.01$ \\
Nitrate-nitrogen $(\mathrm{mg} / \mathrm{L})$ & $0.57 \pm 0.04(30,1.08)$ & $0.53 \pm 0.06(30,1.10)$ & NS \\
\hline
\end{tabular}




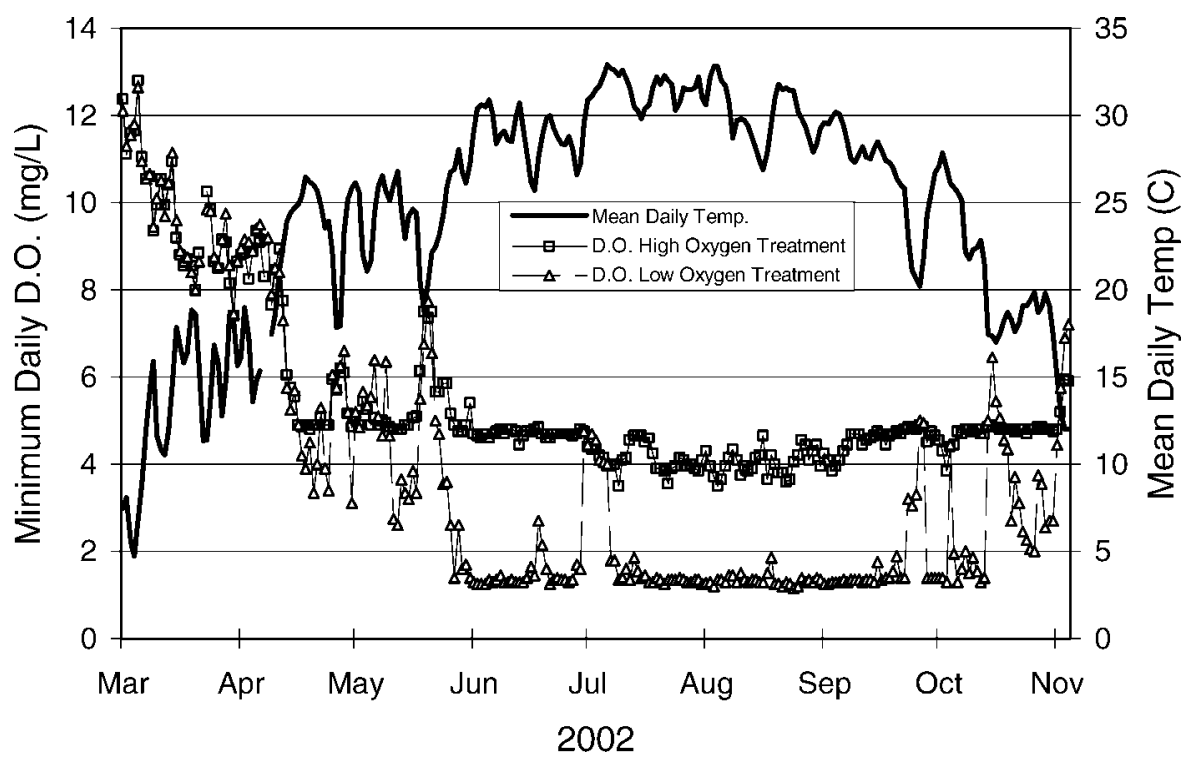

FIGURE 4.-Minimum daily dissolved oxygen (DO) concentration and mean daily temperature in experimental channel catfish ponds in 2002. Values for DO are daily means of the lowest daily DO concentration in two 0.1 ha ponds per treatment; temperature is the mean of 72 daily measurements recorded from one representative pond.

when aeration was not required usually corresponded with a drop in water temperature. From June to September, the mean minimum DO concentration in the high-oxygen treatment averaged $2.7 \mathrm{mg} / \mathrm{L}$ greater than that of the low-oxygen treatment ( $57 \%$ versus $21 \%$ saturation).

The $11.2 \mathrm{~kW} / \mathrm{ha}$ of aeration was not able to maintain the minimum DO concentration as high as desired in the high-oxygen treatment during July and August, when the mean water temperature was $30^{\circ} \mathrm{C}$ or higher (Figure 4). The minimum DO concentration in the high-oxygen treatment averaged $4.1 \mathrm{mg} / \mathrm{L}$ in July and $4.0 \mathrm{mg} / \mathrm{L}$ in August (55\% and 53\% saturation) (Table 6), whereas the values were 4.3 and $4.4 \mathrm{mg} / \mathrm{L}(59 \%$ and $58 \%$ saturation) for those same months in 2001 (Table 2). This difference was presumably due to the extremely high feed input to the high-oxygen treatment ponds (discussed later). As in 2001, there were no significant differences in minimum DO concentration between treatments in March, April, October, or November of 2002, months in which water temperature averaged less than $22^{\circ} \mathrm{C}$.

Feed consumption.-Fish in the high-oxygen treatment ate significantly more feed every month from July to September (Figure 5). Overall feed consumption was $168 \mathrm{~kg} \cdot \mathrm{ha}^{-1} \cdot \mathrm{d}^{-1}(42,331 \mathrm{~kg} / \mathrm{ha}$ total) based on the $252 \mathrm{~d}$ that fish were exposed to the high-oxygen treatment; feed consumption was $92 \mathrm{~kg} \cdot \mathrm{ha}^{-1} \cdot \mathrm{d}^{-1}(23,247 \mathrm{~kg} / \mathrm{ha})$ for the lowoxygen treatment (Table 7 ).

The greatest food consumption for an individual pond on a single day was $680 \mathrm{~kg} / \mathrm{ha}$ in the highoxygen treatment and $436 \mathrm{~kg} / \mathrm{ha}$ in the low-oxygen treatment (data not shown). The greatest monthly food consumption in both treatments occurred in August (Figure 5): average monthly consumption was $328 \mathrm{~kg} \cdot \mathrm{ha}^{-1} \cdot \mathrm{d}^{-1}(10,177 \mathrm{~kg} / \mathrm{ha}$ total $)$ in the high-oxygen treatment and $166 \mathrm{~kg} \cdot \mathrm{ha}^{-1} \cdot \mathrm{d}^{-1}$ $(5,156 \mathrm{~kg} / \mathrm{ha})$ in the low-oxygen treatment $(P \leq$ $0.05)$. From July to September, the three peak feeding months, feed consumption averaged 282 $\mathrm{kg} \cdot \mathrm{ha}^{-1} \cdot \mathrm{d}^{-1}$ for the high-oxygen treatment versus $130 \mathrm{~kg} \cdot \mathrm{ha}^{-1} \cdot \mathrm{d}^{-1}$ for the low-oxygen treatment $(P$ $\leq 0.05)$.

Production.-Net production in 2002 averaged $23,547 \mathrm{~kg} / \mathrm{ha}$ in the high-oxygen treatment versus $10,830 \mathrm{~kg} / \mathrm{ha}$ in the low-oxygen treatment (Table 7; $P<0.05)$. This is the highest net channel catfish production yet reported in earthen ponds. Mean fish weight, although not significantly different, averaged $760 \mathrm{~g}$ in the high-oxygen treatment and $520 \mathrm{~g}$ in the low-oxygen treatment.

Fish survival in the two replicates used per treatment did not differ significantly between treatments (Table 7). However, analysis of covariance of all three replicates per treatment showed a significant difference $(P \leq 0.05)$ in the regression of 


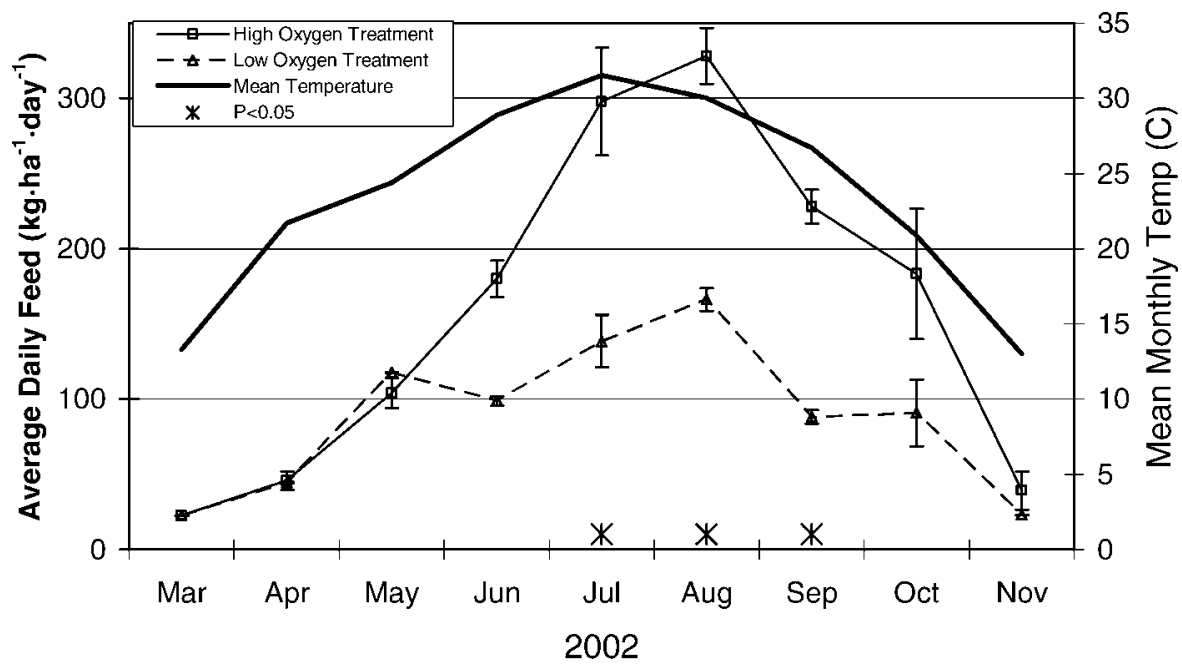

FIGURE 5.-Average $( \pm$ SE) daily feed administered to experimental channel catfish ponds in 2002 . Feed values are monthly means of two replicate ponds per treatment; temperature is the mean value for one representative pond.

survival against mean weight in the two treatments (Figure 6).

Feed conversion.-The mean FCR in 2002 was poorer in the low-oxygen treatment (2.15) than in the high-oxygen treatment (1.80; Table 7); however, this difference was not significant. Some other studies have found a poorer FCR as well as reduced feed consumption at lower DO concentrations (Andrews et al. 1973; Lai-fa and Boyd 1988). At least a part of the difference seen in these studies was due to wasted feed resulting from feeding fish a fixed percentage of their body weight (Andrews et al. 1973) rather than feeding to satiation. However, as feeding rates become progressively reduced (either from management restrictions or water quality induced reductions in voluntary feed consumption), a larger portion of the diet is utilized for maintenance rather than for growth and one would expect a poorer FCR to result. While the trends in these data support that principle, the differences in FCR observed in this study were not statistically significant.
Aeration hours. - The high-oxygen treatment used over six times the amount of aeration $(16,439$ $\mathrm{kW}-\mathrm{h} / \mathrm{ha}$ ) than was used by the low-oxygen treatment $(2,593 \mathrm{~kW}-\mathrm{h} / \mathrm{ha})$ (Table $8 ; P \leq 0.10)$. At a cost of $\$ 0.11$ per kilowatt-hour, this would add $\$ 0.08$ per kilogram to the cost of fish in the highoxygen treatment versus $\$ 0.03$ per kilogram to the cost of fish in the low-oxygen treatment. The aeration required was significantly different between treatments during every month from April to October.

The large difference in aeration between treatments was due primarily to two factors. First, aerator efficiency ( $\mathrm{kg}$ of oxygen transferred per $\mathrm{kW}$ $\mathrm{h}$ of aeration) decreases linearly as DO concentration (and oxygen saturation) increases, since oxygen transfer is proportional to the difference in partial pressure of oxygen between the water and the atmosphere. Thus, under the assumption of equal total pond respiration rates, the maintenance of DO at $5.0 \mathrm{mg} / \mathrm{L}$ would require over three times as much aeration as maintenance at $1.5 \mathrm{mg} / \mathrm{L}$ be-

TABLE 7.-Average $( \pm$ SE) weight, net production, survival, and feed conversion ratio of channel catfish in 0.1-ha earthen ponds (two ponds/treatment) in 2002. Within a row, values followed by different letters are significantly different (ANOVA; $P \leq 0.10$ ).

\begin{tabular}{lcc}
\hline \multicolumn{1}{c}{ Variable } & Low-oxygen treatment & High-oxygen treatment \\
\hline Net production $(\mathrm{kg} / \mathrm{ha})$ & $10,830 \pm 1,728 \mathrm{y}$ & $23,547 \pm 283 \mathrm{z}$ \\
Mean weight $(\mathrm{g})$ & $520 \pm 90$ & $760 \pm 60$ \\
Survival $(\%)$ & $62 \pm 18$ & $83 \pm 6$ \\
Feed administered $(\mathrm{kg} / \mathrm{ha})$ & $23,247 \pm 1,727 \mathrm{y}$ & $42,331 \pm 1,775 \mathrm{z}$ \\
Average feeding rate $\left(\mathrm{kg} \cdot \mathrm{ha}^{-1} \cdot \mathrm{d}^{-1}\right)$ & $92 \mathrm{y}$ & $168 \mathrm{z}$ \\
Feed conversion ratio & $2.15 \pm 0.19$ & $1.80 \pm 0.05$ \\
\hline
\end{tabular}




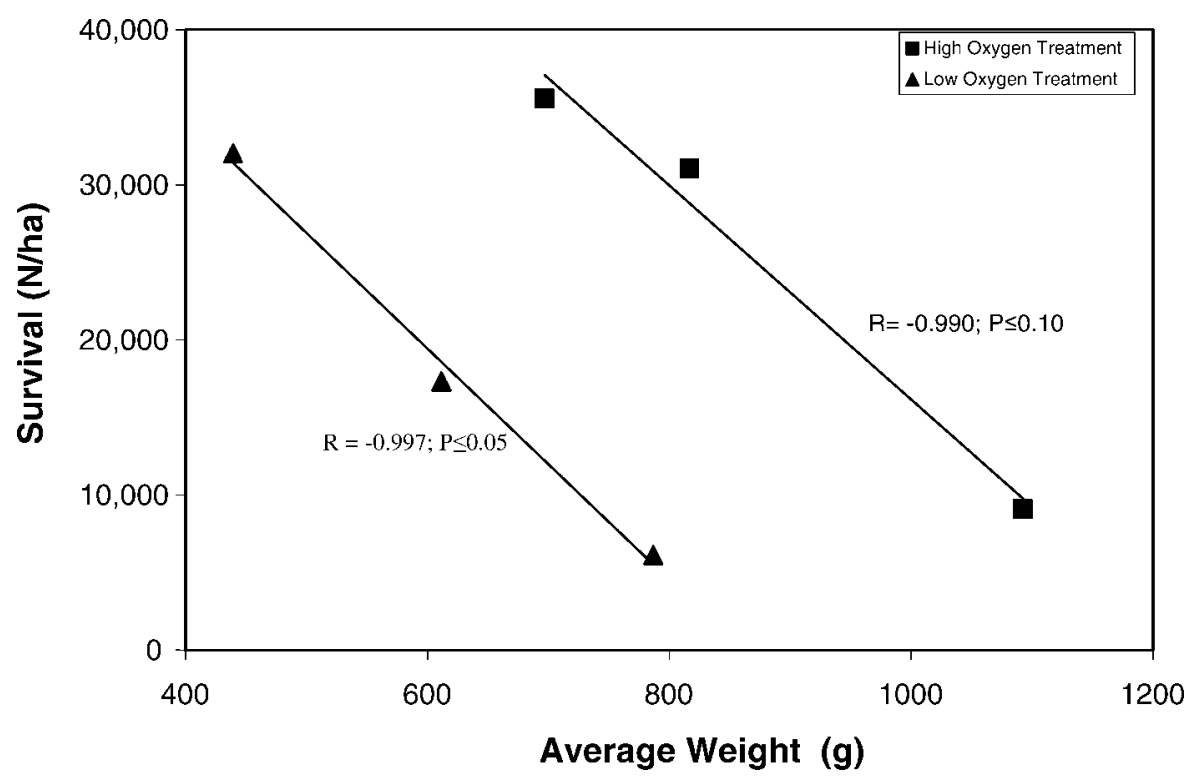

FIGURE 6.-Actual survival (number of fish recovered) versus average weight ( $\mathrm{g}$ ) of channel catfish harvested from experimental ponds in 2002. Data were included from two ponds (one per treatment) that were dropped from the production study because of high mortality.

cause of reduced transfer efficiency in the highoxygen treatment. Second, total pond respiration rates, although not measured directly, were undoubtedly different between the two treatments. The greater feed input to the high-oxygen treatment ponds presumably resulted in a higher total pond oxygen demand, further increasing the need for aeration.

Water quality.-Fish in the high-oxygen treatment consumed $82 \%$ more feed than fish in the low-oxygen treatment in 2002 (calculated from Ta-

TABLE 8.-Aeration levels (kilowatt-hours $[\mathrm{kW}-\mathrm{h}] / \mathrm{ha}$ mean $\pm \mathrm{SE}$ ) in experimental channel catfish ponds (two ponds/treatment) in 2002. Temperature is the mean monthly temperature $\left({ }^{\circ} \mathrm{C}\right)$ measured in one representative pond. Within a row, values followed by different letters are significantly different (ANOVA; $P \leq 0.10$ ).

\begin{tabular}{lccc}
\hline & \multicolumn{2}{c}{ Aeration } & \\
\cline { 2 - 3 } Month & $\begin{array}{c}\text { Low-oxygen } \\
\text { treatment }\end{array}$ & $\begin{array}{c}\text { High-oxygen } \\
\text { treatment }\end{array}$ & Temperature \\
\hline Mar & $0 \pm 0$ & $0 \pm 0$ & 13.3 \\
Apr & $0 \pm 0 \mathrm{y}$ & $152 \pm 50 \mathrm{z}$ & 21.7 \\
May & $23 \pm 14 \mathrm{y}$ & $542 \pm 57 \mathrm{z}$ & 24.4 \\
Jun & $422 \pm 31 \mathrm{y}$ & $2,129 \pm 213 \mathrm{z}$ & 28.9 \\
Jul & $766 \pm 176 \mathrm{y}$ & $3,679 \pm 843 \mathrm{z}$ & 31.5 \\
Aug & $635 \pm 223 \mathrm{y}$ & $4,019 \pm 864 \mathrm{z}$ & 30.0 \\
Sep & $585 \pm 120 \mathrm{y}$ & $3,764 \pm 358 \mathrm{z}$ & 26.7 \\
Oct & $163 \pm 83 \mathrm{y}$ & $2,118 \pm 398 \mathrm{z}$ & 20.9 \\
Nov & $0 \pm 0$ & $20 \pm 10$ & 13.0 \\
Total & $2,593 \pm 577 \mathrm{y}$ & $16,439 \pm 2,679 \mathrm{z}$ & \\
\hline
\end{tabular}

ble 7), and this impacted many of the water quality variables measured. Total ammonia nitrogen, unionized ammonia nitrogen, and volatile solids did not differ significantly among treatments over the season; however, all other variables did differ significantly among treatments (repeated-measures ANOVA: $P \leq 0.05$ or $P \leq 0.01$; Table 9).

Most variables exhibited the same general seasonal trends demonstrated by temperature and feed input, increasing through the growing season and decreasing in the fall as temperatures dropped and feed input was reduced. However, there was great variation both among sample dates and among replicate ponds on given dates.

Total ammonia nitrogen increased through the spring and into the summer as feed input increased, reaching high mean values on July 24 of $4.0 \mathrm{mg}$ / $\mathrm{L}$ in the high-oxygen treatment and $2.6 \mathrm{mg} / \mathrm{L}$ in the low-oxygen treatment. The highest values measured in individual ponds were $4.7 \mathrm{mg} / \mathrm{L}$ in the high-oxygen treatment and $4.4 \mathrm{mg} / \mathrm{L}$ in the lowoxygen treatment (Table 9). However, over the course of the season, TAN averaged slightly (but not significantly) lower in the high-oxygen treatment than in the low-oxygen treatment. This trend, observed in both years, indicates an increased nitrification rate resulting from the higher DO concentrations (Avnimelech et al. 1986), increased volatization resulting from increased mechanical 
TABLE 9.-Water quality variables (mean $\pm \mathrm{SE} ; N$ and maximum value in parentheses) for experimental channel catfish ponds (two ponds/treatment) in 2002. Measurements were taken at approximately weekly intervals throughout the study. The last column indicates the results of a repeated-measures ANOVA testing for significant differences between treatments $(\mathrm{NS}=$ not significant).

\begin{tabular}{|c|c|c|c|}
\hline Variable & Low-oxygen treatment & High-oxygen treatment & $P$ \\
\hline Total ammonia nitrogen (mg/L) & $1.26 \pm 0.12(60,4.36)$ & $1.20 \pm 0.11(60,4.70)$ & NS \\
\hline Un-ionized ammonia nitrogen $(\mathrm{mg} / \mathrm{L})$ & $0.05 \pm 0.01(58,0.16)$ & $0.06 \pm 0.01(58,0.18)$ & NS \\
\hline $\mathrm{pH}$ & $7.92 \pm 0.03(58,8.76)$ & $8.00 \pm 0.02(58,8.70)$ & $\leq 0.01$ \\
\hline Nitrite-nitrogen (mg/L) & $0.35 \pm 0.04(60,1.47)$ & $0.56 \pm 0.06(60,3.16)$ & $\leq 0.01$ \\
\hline Nitrate-nitrogen (mg/L) & $0.30 \pm 0.04(60,1.73)$ & $0.53 \pm 0.09(60,3.99)$ & $\leq 0.05$ \\
\hline Chlorophyll $a(\mu \mathrm{g} / \mathrm{L})$ & $342 \pm 32 \quad(54,1,045)$ & $439 \pm 39 \quad(54,1,040)$ & $\leq 0.01$ \\
\hline Secchi visibility $(\mathrm{cm})$ & $16.7 \pm 0.5 \quad(54,26)$ & $15.0 \pm 0.4 \quad(54,25)$ & $\leq 0.05$ \\
\hline Total suspended solids (mg/L) & $(54,233)$ & $(54,257)$ & $\leq 0.05$ \\
\hline Fixed solids (mg/L) & $(54,152)$ & $(54,195)$ & $\leq 0.05$ \\
\hline Volatile solids (mg/L) & $(54,91)$ & $(54,101)$ & NS \\
\hline
\end{tabular}

aeration (Weiler 1979), and/or an increased ammonia utilization by the denser phytoplankton bloom (Hargreaves and Tucker 1996).

Un-ionized ammonia also increased through the season, peaking in September at mean concentrations of less than $0.15 \mathrm{mg} / \mathrm{L}$ in both treatments. While this variable did not differ between treatments over the season $(P \geq 0.05$; Table 9$)$, mean un-ionized ammonia did average slightly higher in the high-oxygen treatment even though average TAN was slightly lower in that treatment. This was due to the higher $\mathrm{pH}(P \leq 0.01$; Table 9$)$ in the high-oxygen treatment throughout the season. The higher $\mathrm{pH}$ in the high-oxygen treatment probably resulted from the greater aeration, which removes free $\mathrm{CO}_{2}$, thus raising the $\mathrm{pH}$ (Hargreaves and Brunson 1996) and increasing the proportion of un-ionized ammonia (Emerson et al. 1975). The highest un-ionized ammonia values measured in individual ponds were $0.18 \mathrm{mg} / \mathrm{L}$ in the highoxygen treatment and $0.16 \mathrm{mg} / \mathrm{L}$ in the low-oxygen treatment (Table 9). These are well below the concentrations shown to have an effect on channel catfish food consumption or growth (Hargreaves and Kucuk 2001).

Peaks in nitrite-nitrogen concentration usually occurred 1 week after peaks in TAN (ponds were only sampled once per week). Nitrite-nitrogen differed significantly between treatments over the season $(P \leq 0.01$; Table 9$)$, and this was expected in ponds that received more aeration (Hollerman and Boyd 1980). The highest values measured in individual ponds were $3.16 \mathrm{mg} / \mathrm{L}$ in the highoxygen treatment and $1.47 \mathrm{mg} / \mathrm{L}$ in the low-oxygen treatment. While these values are high enough to be of interest, they are well below the tolerance level of channel catfish based on the chloride concentrations that were maintained (Tomasso et al. 1980; Brunson 1997; Durborow et al. 1997).
Chlorophyll $a$ was significantly higher in the high-oxygen treatment (mean, $439 \mu \mathrm{g} / \mathrm{L}$ ) than in the low-oxygen treatment (342 $\mu \mathrm{g} / \mathrm{L}$; Table 9). Chlorophyll $a$ is normally light-limited in intensive eutrophic channel catfish production ponds, which diurnally stratify. However, it does appear that the phytoplankton bloom in these ponds, which were continually circulated and thoroughly mixed, could still respond to increased nutrient input. The denser phytoplankton bloom in the high-oxygen treatment was at least partly responsible for the low (relative to feed input) ammonia concentrations.

The high-oxygen treatment ponds were more turbid and had significantly lower Secchi disk visibility and significantly more total suspended solids than the low-oxygen ponds (Table 9). Nonvolatile (fixed) suspended solids were significantly higher in the high-oxygen treatment overall, while volatile suspended solids were not significantly different between the two treatments. The sixfold higher aeration in the high-oxygen treatment was expected to yield higher total suspended solids and fixed solids and a reduced Secchi visibility (Thomforde and Boyd 1991; Teichert-Coddington and Green 1993); however, the fact that volatile solids were not significantly different between treatments cannot be explained.

Feed consumption versus minimum DO concentration.-In both years of the study, a high-oxygen treatment was established in which aeration was initiated when the DO concentration dropped below $5.0 \mathrm{mg} / \mathrm{L}$. These treatments were used as controls (maximum feed consumption) against which response to the low-oxygen treatment of the same year could be compared. When the minimum DO concentration was allowed to fall to $2.5 \mathrm{mg} / \mathrm{L}$ before initiating aeration (resulting in a mean minimum May-September DO concentration of 2.7 
$\mathrm{mg} / \mathrm{L}$ or $35 \%$ saturation; Table 2), this produced only a $6.3 \%$ reduction in feed consumption in 2001 (Table 3). In 2002, when the DO concentration in the low-oxygen treatment was allowed to decrease to $1.5 \mathrm{mg} / \mathrm{L}$ before initiating aeration (resulting in a mean minimum June-September DO concentration of $1.7 \mathrm{mg} / \mathrm{L}$ or $21 \%$ saturation; Table 6 ), feed consumption was reduced by $45.1 \%$ (Table 7 ).

\section{Conclusions}

Channel catfish are tolerant of the low DO concentrations that are common in eutrophic warmwater aquaculture ponds. While exposure to a constant DO concentration as high as $60 \%$ saturation negatively affects channel catfish oxygen consumption (Andrews and Matsuda 1975), feed consumption, and growth (Andrews et al. 1973; Raible 1975; Carlson et al. 1980; Buentello et al. 2000), this study demonstrated that channel catfish can tolerate periodic exposure to low oxygen concentrations in a diurnally cycling pond environment without a reduction in culture performance.

Maintaining DO concentrations above $2.5 \mathrm{mg} /$ L (32\% saturation) would be energy inefficient due to the poor oxygen transfer of existing surface aerators, and the gains in fish production would be insignificant. However, allowing the DO to decrease below that concentration results in increasingly poor fish performance. When the DO concentration was allowed to decline to $1.5 \mathrm{mg} / \mathrm{L}$ (19\% saturation) before aeration was initiated, voluntary feed consumption was reduced by $45.1 \%$.

Although Andrews et al. (1973) observed a reduction in feed efficiency when fish were exposed to constant low DO $\left(2.9 \mathrm{mg} / \mathrm{L}\right.$ at a $26.6^{\circ} \mathrm{C}$ test temperature), that was not observed in this study (Tables 3,7). While the mean FCR of the lowoxygen treatment was slightly poorer than that of the high-oxygen treatment $(2.15$ versus 1.80 in 2002; Table 7), the difference was not significant. However, it is likely that if minimum DO concentrations were allowed to decrease further (or if a constant low DO concentration was maintained, as in the Andrews et al. 1973 study), feed consumption would be reduced even more than was observed in this study and feed conversion could be affected, as a greater portion of the feed consumed would be required for maintenance.

Reduced feed consumption resulting from lower DO concentrations means a significantly reduced growth rate even if FCR is not affected. At the higher stocking rates used in 2002, the difference in growth due to reduced feed consumption was $350 \mathrm{~g}(0.8 \mathrm{lbs})$ at a similar survival: density ratio (calculated from Figure 6). In addition to producing a greater standing crop, faster growth would allow harvest of fingerlings stocked in the spring after only one season of growth rather than after two growing seasons, which is typical of existing commercial farms. This increased growth rate would eliminate the risks and losses incurred from holding sub-marketable fish at high densities over winter and through the following spring.

If aeration is not initiated before the DO concentration has fallen to $2.5 \mathrm{mg} / \mathrm{L}$ or if there are not enough aerators available to maintain DO concentrations in the $2.2-2.5 \mathrm{mg} / \mathrm{L}$ range, both feed consumption and production will be negatively affected. Both of those aeration conditions were met in this study; thus, it appears we may not yet have reached the limit to fish production possible in earthen ponds, as has been speculated (Brune et al. 2003).

A maximum feeding rate of $120 \mathrm{~kg} \cdot \mathrm{ha}^{-1} \cdot \mathrm{d}^{-1}$ in channel catfish ponds with $3.73 \mathrm{~kW} / \mathrm{ha}(2 \mathrm{hp} /$ acre) of aeration permanently installed has been recommended (Auburn University and Natural Resources Conservation Service 2002; Brune et al. 2003). In this study, a monthly average feeding rate as high as $328 \mathrm{~kg} \cdot \mathrm{ha}^{-1} \cdot \mathrm{d}^{-1}$ (Figure 5; highoxygen treatment, August 2002) was achieved, indicating that a continued relationship exists between feed input and aeration up to $11 \mathrm{~kW} / \mathrm{ha}(6$ hp/acre).

While the relationship between increased aeration and increased feeding and production rates determined in this study should apply in large ponds, the specific results of this production study conducted in 0.1-ha ponds cannot be directly extrapolated to large commercial ponds. The small ponds used in this study were thoroughly circulated and destratified, which may have had a positive impact on water quality. Similar mixing in a large commercial pond would be difficult to achieve, and thus the effect of higher feeding rates on water quality cannot be predicted. Although commercial production rates may be increased far above that currently seen, actual production achieved on individual farms will be a function of risk tolerance, management skills, and economic factors such as cost of electricity and feed and the market price of channel catfish.

\section{Acknowledgments}

I would like to express my deep appreciation to T. I. Walls for her invaluable assistance with this project. I would also like to thank C. Tucker and $\mathrm{S}$. Kingsbury for their guidance and assistance 
with water quality analytical methods; C. Tucker for his encouragement and inspiration; T. Bates, E. Allen, R. Mascagni, M. Lofton, S. Patterson, B. Keene, and C. Sherman for their assistance at various times during this study; and C. Tucker, J. Hargreaves, B. Small, B. Peterson, B. Bosworth, G. Waldbieser, B. Green, C. Mischke, M. Masser, J. Steeby, M. Li, and S. Kingsbury for their critical reviews of the manuscript. This project was conducted with funding provided by USDA-ARS Current Research Information System Project 13320002-00D. Mention of trade names or commercial products in this article is solely for the purpose of providing specific information and does not imply recommendation or endorsement by the USDA.

\section{References}

American Public Health Association, American Water Works Association, and Water Environment Federation. 1998. Standard methods for the examination of water and wastewater, 20th edition. American Public Health Association. Washington, D.C.

Andrews, J. W., and Y. Matsuda. 1975. The influence of various culture conditions on the oxygen consumption of channel catfish. Transactions of the American Fisheries Society 104:322-327.

Andrews, J. W., T. Murai, and G. Gibbons. 1973. The influence of dissolved oxygen on the growth of channel catfish. Transactions of the American Fisheries Society 102(4):835-838.

Auburn University and Natural Resources Conservation Service. 2002. Best management practices for channel catfish farming, U.S. Department of Agriculture, Natural Resource Conservation Service, Alabama Guide Sheets 1-15, Auburn, Alabama.

Avnimelech, Y., B. Weber, B. Hepher, B. Milstein, and M. Zorn. 1986. Studies in circulated fish ponds: organic matter recycling and nitrogen transformation. Aquaculture and Fisheries Management 17: 231-242.

Boyd, C. E., J. A. Steeby, and E. W. McCoy. 1980. Frequency of low dissolved oxygen concentrations in ponds for commercial culture of channel catfish. Proceedings of the Annual Conference Southeastern Association of Fish and Wildlife Agencies 33(1979): 591-599.

Boyd, C. E., and C. S. Tucker. 1992. Water quality and pond soil analyses for aquaculture. Alabama Agricultural Experiment Station, Auburn University, Alabama.

Brune, D. E., G. Schwartz, A. G. Eversole, J. A. Collier, and T. E. Schwedler. 2003. Intensification of pond aquaculture and high-rate photosynthetic systems. Aquacultural Engineering 28:65-86.

Brunson, M. W. 1997. Brown blood disease. Mississippi State University Cooperative Extension Service, Information Sheet 1390, Starkville.

Buentello, J. A., D. M. I. Gatlin, and W. H. Neill. 2000. Effects of water temperature and dissolved oxygen on daily feed consumption, feed utilization, and growth of channel catfish (Ictalurus punctatus). Aquaculture 182(3-4):339-352.

Busch, C. D., and R. K. Goodman. 1981. Water circulation: an alternative to emergency aeration. Journal of the World Mariculture Society 12(1):13-19.

Busch, R. L., C. S. Tucker, J. A. Steeby, and J. E. Reames. 1984. An evaluation of three paddlewheel aerators used for emergency aeration of channel catfish ponds. Aquaculture Engineering 3:59-69.

Carlson, A. R., J. Blocher, and L. J. Herman. 1980. Growth and survival of channel catfish and yellow perch exposed to lowered constant and diurnally fluctuating dissolved oxygen concentrations. Progressive Fish-Culturist 42:73-78.

Cathcart, T. P., J. W. Pote, and D. W. Rutherford. 1999. Reduction of effluent discharge and groundwater use in catfish ponds. Aquaculture Engineering 20: 163-174.

Chowdhury, A. Q. 1971. Respiratory metabolism of channel catfish Ictalurus punctatus (Rafinesque), with respect to temperature and growth. Master's thesis. University of Oklahoma, Norman.

Durborow, R. M., J. W. Avault, Jr., W. A. Johnson, and K. L. Koonce. 1985. Differences in mortality among full-sib channel catfish families at low dissolved oxygen. Progressive Fish-Culturist 47(1): 14-20.

Durborow, R. M., M. D. Crosby, and M. W. Brunson. 1997. Nitrite in fish ponds. Southern Regional Aquaculture Center, SRAC Publication 462, Stoneville, Mississippi.

Emerson, K., R. C. Russo, R. E. Lund, and R. V. Thurston. 1975. Aqueous ammonia equilibrium calculations: effect of $\mathrm{pH}$ and temperature. Journal of the Fisheries Research Board of Canada 32:2379-2383.

Hargreaves, J. A. and M. W. Brunson. 1996. Carbon dioxide in fish ponds. Southern Regional Aquaculture Center, SRAC Publication 468, Starkville, Mississippi.

Hargreaves, J. A., and S. Kucuk. 2001. Effects of diel un-ionized ammonia fluctuation on juvenile hybrid striped bass, channel catfish, and blue tilapia. Aquaculture 195(1-2):163-181.

Hargreaves, J. A., and J. A. Steeby. 2000. Factors affecting metabolism of commercial channel catfish ponds as indicated by continuous dissolved oxygen measurement. Journal of the World Aquaculture Society 30(4):410-421.

Hargreaves, J. A., and C. S. Tucker. 1996. Evidence for control of water quality in channel catfish Ictalurus punctatus ponds by phytoplankton biomass and sediment oxygenation. Journal of the World Aquaculture Society 27(1):21-29.

Hollerman, W. D., and C. E. Boyd. 1980. Nightly aeration to increase production of channel catfish. Transactions of the American Fisheries Society 109: 446-452.

Lai-fa, Z., and C. E. Boyd. 1988. Nightly aeration to increase the efficiency of channel catfish production. Progressive Fish-Culturist 50(4):237-242.

Lloyd, S. W., and C. S. Tucker. 1988. Comparison of 
three solvent systems for extraction of chlorophyll $a$ from fish pond phytoplankton communities. Journal of the World Aquaculture Society 19(2):36-40.

Moss, D. D., and D. C. Scott. 1961. Dissolved oxygen requirements of three species of fish. Transactions of the American Fisheries Society 90:377-393.

New catfish broodstock moved to growers. 2001. The Catfish Journal (March):1, 16.

Raible, R. W. 1975. Survival and growth rate of channel catfish as a function of dissolved-oxygen concentration. Arkansas Water Resources Research Center, Publication 33, Fayetteville.

SAS Institute. 1999a. SAS/STAT, version 8. 01. SAS Institute, Cary, North Carolina.

SAS Institute. 1999b. The analyst application. SAS Institute, Cary, North Carolina.

Swingle, H. S. 1959. Experiments on growing fingerling channel catfish to marketable size in ponds. Proceedings of the Annual Conference Southeastern Association of Game and Fish Commissioners 12(1958):63-74.

Teichert-Coddington, D., and B. W. Green. 1993. Tilapia yield improvement through maintenance of minimal dissolved oxygen concentrations in experimental grow-out ponds in Honduras. Aquaculture 118:6371.

Thomforde, H. W., and C. E. Boyd. 1991. Effects of aeration on water quality and channel catfish production. Bamidgeh 43(1):3-26.

Tomasso, J. R., M. I. Wright, B. A. Simco, and K. B.
Davis. 1980. Inhibition of nitrite-induced toxicity in channel catfish by calcium chloride and sodium chloride. Progressive Fish-Culturist 42:144-146.

Tucker, C. S., and C. E. Boyd. 1978. Consequences of periodic applications of copper sulfate and simazine for phytoplankton control in catfish ponds. Transactions of the American Fisheries Society 107:316320.

Tucker, C. S., and E. H. Robinson. 1990. Channel catfish farming handbook. Van Nostrand Reinhold, New York.

Tucker, C. S., and J. A. Steeby. 1995. Daytime mechanical water circulation of channel catfish ponds. Aquaculture Engineering 14:15-27.

Tucker, L., C. E. Boyd, and E. W. McCoy. 1979. Effects of feeding rate on water quality, production of channel catfish, and economic returns. Transactions of the American Fisheries Society 108:389-396.

USDA (U.S. Department of Agriculture). 1997. NAHMS national catfish study, part I. Reference of 1996 U.S. catfish health and production practices; and part II. Reference of 1996 U.S. catfish management practices. USDA, Animal and Plant Health Inspection Service, Veterinary Services, Fort Collins, Colorado. Available: http://www.aphis.usda. gov/vs/ceah/ncahs/nahms/aquaculture/index.htm\# catfish97. (July 2005).

Weiler, R. R. 1979. Rate of loss of ammonia from water to the atmosphere. Journal of the Fisheries Research Board of Canada 36:685-689. 